\title{
Social Justice and Lesbian Feminism: Two Theories Applied to Homophobia
}

\author{
Denise L. Leyy
}

\begin{abstract}
Trends in contemporary social work include the use of an eclectic theory base. In an effort to incorporatemultipletheories, this articlewill examinethe social problem of homophobia using two different theoretical perspectives: John Rawls' the ory of social justiceand lesbian feminist theory. Homophobia, a current social problem, can be defined as "di slike or hatred toward homosexuals, including both cultural and personal biases against homosexuals" (Sullivan, 2003, p. 2). Rawls' theory of justiceand lesbian feminist theoryareespecially relevant to theissue of homophobia and provide a useful lens to understanding this social problem. In this article, these two theories will besummarized, applied to theissue of homophobia, and compared and contrasted based on their utility.
\end{abstract}

Keywords: Homophobia, theory, lesbian feminism, social justice

$\mathrm{P}$

racticing social workers encounter a wide variety of client situations that often require the use of multiple theories and interventions. It is important for social workers to be able to use a range of theories to inform their practice with unique clients (Lehmann \& Coady, 2001). The more tools that social workers have at their disposal, the better equipped they will be to help clients. In fact, "the valuing of multiple perspectives for understanding and intervening ... are consistent with and can inform social work practice" (Lehmann \& Coady, 2001, p. 13). In this spirit, this article will examine the social problem of homophobia using two different theoretical perspectives: John Rawls' theory of social justice and lesbian feminist theory.

Homophobia is an important concern for social workers today. According to the National Association of Social Workers (NASW, 1999) Code of Ethics, social workers should understand oppression based on sexual orientation, advocate for equal access and equal rights for all individuals, promote respect for diversity, and work to end social injustice and discrimination against individuals based on their sexual orientation. First and foremost among these directives is the call for social workers to understand oppression, which includes homophobia.

Denise L. Levy is an assistant professor at the Department of Social Work, Appalachian State University, Boone, NC 28608.

Copyright $^{\circ} 2007$ Advances in Social Work Vol. 8 No. 2 (Fall 2007) 319-327.

Indiana University School of Social Work. 
In defining homophobia, it should be distinguished from heterosexism. Lorde (2001) defined homophobia as "a terror surrounding feelings of love for members of the same sex and thereby a hatred of those feelings in others" ( $p$. 234). On the other hand, heterosexism is the societal superiority of heterosexuality (Krieglstein, 2003; Lorde, 2001). In other words, homophobia signifies an individual's beliefs or feelings about homosexuals; the broader term, heterosexism, deals with the denial of privilege to non-heterosexuals at the societal level (Simoni \& Walters, 2001). These concepts are certainly intertwined, and both will be addressed in this article. Furthermore, although the focus is on homophobia against gay and Iesbian individuals, this discussion is certainly relevant to discrimination against other queer populations.

In an effort to better understand homophobia, this article will examine this social problem through the lens of two theories: John Rawls' theory of justice and lesbian feminist theory. Specifically, there will be a focus on the contribution of each perspective to understanding homophobia. The two theories will be compared based on their utility and their implications for social work practice.

\section{RAWLS'THEORY OF JUSTICE}

\section{Basics of the Theory}

John Rawls, born in 1921, was a major American political theorist (Martin, 2002). Rawls' book, A Theory of Justice, published in 1971, "stimulated a revival of attention to moral philosophy . . . [and] made a sophisticated argument for a new concept of justice, based on simple fairness" (Martin, 2002, p. 19). This theory is certainly relevant to social work, especially considering the profession's value of social justice (NASW, 1999). Furthermore, this theory, as outlined below, can provide a unique framework in which to view and examine homophobia. John Rawls' theory of justice includes three main concepts: reflective deliberation, the original position, and a well-ordered society.

Reflective Deliberation. In reflective deliberation, rational people generate ideas regarding what is just or right, as well as what is unjust or wrong. In other words, individuals deliberate and reflect on what is just in order to come up with considered judgments (Kaufman, 2006). These considered judgments are simply a list of what individuals find to be right through the reflective deliberation process. Once considered judgments are identified, they can be tested using the original position (Rawls, 2001).

The Original Position. In the original position, individuals are blinded to their position, status, and wealth in society as they debate considered judgments (Rawls, 2001). For example, if a rational individual does not know whether he or she will be rich or poor, that individual will most likely advocate for programs to assist underprivileged groups. Because individuals do, in fact, know their positions in society, the original position is more of a thought experiment than a reality. However, utilizing this "veil of ignorance," in which individuals test principles of justice while being ignorant of their positions in society, is certainly useful (Rawls, 2001). The idea is that individuals will act in 
their best interest but, without knowing their eventual societal status, they will choose principles of justice that are beneficial to everyone. Essentially, individuals will approve principles that forbid anyone from being oppressed so that they can keep from being exploited themselves (Nathanson, 1998).

If the considered judgments do not stand up to the hypothetical test of the original position, further reflection and deliberation is needed. Rawls (2001) explained that:

By going back and forth [between reflective deliberation and the original position] ... I I assume that eventually we shall find a description of the initial situation that both expresses reasonable conditions and yields principles which match our considered judgments duly pruned and adjusted. This state of affairs I refer to as reflective equilibrium ( $p$. 58).

Rawls asserted that reflective equilibrium will lead to the formation of two central principles of justice: the liberty and difference principles (Rawls, 2001; Nathanson, 1998).

A Well-Ordered Society. Rawls (2001) explained that the process of reflective equilibrium will always lead to the liberty and difference principles. The liberty principle outlines basic human rights and states that all people will have equal rights in a just society (Nathanson, 1998). The difference principle, though it does allow for some economic inequalities, focuses on providing the greatest benefit to those who are least advantaged (Nathanson, 1998). This entire process of reflective discourse and the original position leads to and is based on a well-ordered society, or a society in which every member follows and adheres to the principles of justice.

\section{Assumptions}

Rawls' theory of justice includes several assumptions and may not be considered a very practical theory. For example, critics might question the utility and value of a hypothetical thought experiment. In fact, as everyone knows their place in society, the "veil of ignorance" is impossible. However, the theoretical situation is useful in contemplating social justice and principles of justice in a new way. This theory also posits that we live in a well-ordered society, and Rawls (2001) acknowledged this as a limitation. Finally, Rawls (2001) assumed that individuals in the original position will always come up with his two principles of justice: the liberty and differences principles. It is, in fact, the difference principle that highlights one of the main assumptions of this theorythe assumption of deep inequalities in society (Rawls, 2001).

\section{Definition of Homophobia}

Rawls' theory of justice does not specifically speak to the social problem of homophobia. This issue may not be addressed simply because the theory is designed as a thought experiment and is not applied, by Rawls anyway, to everyday issues and problems. However, based on an understanding of the theory itself, inferences can be made regarding how it can be used to understand homophobia. In the theory of justice, the first principle is concerned 
with basic human rights and liberties. The second deals with greater assistance to the least advantaged in a society. Rawls' theory, therefore, would characterize homophobia and heterosexism as removing these liberties and continuing the cycle of oppressing the least advantaged. Rawls (2001) explained that basic liberties include "freedom of the person, which includes freedom from psychological oppression and physical assault and dismemberment (integrity of the person)" (p. 60). Consequently, homophobia would be defined as the psychological oppression of gay and lesbian individuals. This oppression would go against respect and self-respect, which Rawls "regards as a primary social good-a value more important than money and power" (Jones, 1980, p. 286).

\section{Causes of Homophobia}

Although the theory of justice does not specifically describe the causes of social injustices and social problems, these can be inferred. Using the definition of homophobia as the psychological oppression of homosexuals, the theory could identify a variety of causes of this social problem. For example, Nathanson (1998) discussed the importance of self-interest in Rawls' theory:

To take account of these facts about human motivation, Rawls assumes that people in the original position are concerned with advancing their own interests. They want to make sure that their own lives will go well, and they want principles of justice that will protect them from various kinds of bad conditions (p. 83).

In society, some individuals are totally motivated by self-interest and, knowing their position in society, they want what is best for them and for those like them. If these individuals are part of the heterosexual majority, then the result could be heterosexism and limited opportunities for gay and lesbian individuals.

Homophobia might also be caused by individuals who have not tested their considered judgments in the original position. These individuals, for example, might be surrounded with others who are homophobic and never question this belief. If examined using the Rawls' "veil of ignorance," though, homophobia would be discarded as unjust.

Another cause of homophobia could be discriminatory religious views. Rawls explained that principles of justice must be just in and of themselves, and he discouraged any appeal to a religious or moral authority when deciding these principles (Rawls, 1999). However, people do defer to their religion for what is right, moral, and just. Because many forms of Christianity, for example, consider homosexuality to be a sin (Buchanan, Dzelme, Harris, \& Hecker, 2001), the result could be fear of and prejudice against homosexuals.

Rawls' theory of justice assumes that social problems and inequalities exist in society, but it does not explicitly discuss causes of these issues. Therefore, in inferring causes based on the tenets of the theory, the result might be less than satisfying. For example, the social justice perspective does not account for homophobia being caused by lack of contact with homosexuals. 


\section{Solutions and Implications}

Rawls' theory provides a thought experiment in which to test our considered judgments about what is right and wrong. This, in and of itself, can be a solution to homophobia. The original position provides a way for individuals to suppose that they do not know whether they will be gay, lesbian, bisexual, transgendered, queer, or straight. Because of self-interest and other principles at work in the original position, individuals will not likely stand for homophobia to be considered just in a society if they do not know what their sexual orientation would be. Any rational individual who goes through this hypothetical situation will acknowledge that homophobia is unjust. Because the "veil of ignorance" is not truly possible, we are left with the question-what practical solutions, then, does this theory provide to this social problem?

Rawls explains that the original position will lead to the formation of two principles of justice (Rawls, 2001). If applied across a society, these two principles can encourage social justice and discourage social injustice. Furthermore, in employing the liberty principle, all prejudice against gay and lesbian individuals would be considered unjust. In addition to equal liberties, gays and lesbians would be given greater assistance under the difference principle. Though it does allow for economic inequalities, the difference principle states that the greatest benefits must be provided to those who are least advantaged (Nathanson, 1998). Because social workers have historically been concerned with social justice and empowering the least advantaged in society, this theory provides an appropriate framework for interventions. It supports social workers in their efforts to raise awareness about homophobia and heterosexism, lobbying politicians regarding related issues, petitioning teachers and educators concerning school curriculum changes, and increasing community outreach programs to gay and lesbian individuals.

\section{LESBIAN FEMINIST THEORY}

\section{Basics and Assumptions}

Lesbian feminist theory had its beginnings in the 1970s with lesbians who felt like they did not have a place in the radical feminist women's movement (Saulnier, 1996; Stein, 1997). The early lesbian feminist movement joined together:

1) lesbians who felt denied, silenced, or even expelled from the women's movement by heterosexual feminists; 2) lesbians who were dismayed by the inability of the gay movement to incorporate lesbian perspectives; and 3 ) radical feminists whose analysis of sexism extended to an analysis of heterosexism (pp. 76-77).

These individuals, despite their differences, held a couple of the same central beliefs: lesbians should not be devalued based on their sexual orientation; and heterosexism, rather than patriarchy, should be the primary focus of the feminist movement (Garber, 2001). These women believed that heterosexuality eliminated the solidarity between women, lesbianism was a political choice, and that women often experienced compulsory heterosexuality (Enns, 1997; Hawkesworth, 2006). 
Although Saulnier (1996) referred to lesbian feminist theory, the term "lesbian feminism" often signifies the movement itself. This article will utilize the central ideas from the lesbian feminist movement as a unique theory or standpoint by which to analyze homophobia. In fact, Jackson and Jones (1998) explained that lesbian feminist theory, rather than emerging from academia, is one of the few theories based on experience. Further, contemporary scholars tend to refer to lesbian feminism as a theory (Enns, 1997; Enns \& Sinacore, 2005; Jackson \& Jones, 1998; Lehmann \& Coady, 2001).

Lesbian feminist theory is a causal theory. It outlines very clearly the causes of social problems, such as homophobia, and it proposes suggestions for how to rectify these issues. In fact, a core ambition of the lesbian feminist movement was to create a sort of lesbian nation, which might end homophobia (Garber, 2001). To be a lesbian feminist in the 1970s was to be political, and the politics of the woman-identified-woman focused on patriarchy and male privilege (Bunch, 2001; Stein, 1997).

Lesbian feminist theory is based on multiple assumptions, including one that makes this theory distinct from other feminist perspectives: eliminating patriarchy in our society will not necessarily produce an end to heterosexism (Saulnier, 1996). In addition, Iesbian feminists assumed that sexuality would be the most important part of a lesbian's identity (Stein, 1997). They believed that a separate movement was needed in order for lesbians to find their rightful place in feminism. Furthermore, they concluded that the best way to accomplish feminist goals was for women to join together independently from men (Saulnier, 1996).

\section{Definition of Homophobia}

Some lesbian feminists use the term "homophobia" as synonymous with heterosexism (Saulnier, 1996). They do not differentiate between an individual's homophobia, the assumption of heterosexuality, and beliefs in the superiority of heterosexuality (Saulnier, 1996). Therefore, this theory includes the following individuals as homophobic: those who are prejudiced against homosexuals, those who fear homosexuals, and those who believe that heterosexuality is superior.

\section{Causes of Homophobia}

The cause of homophobia, when viewed from a lesbian feminist perspective, is the power and value that society gives to heterosexuals. In this theory, homophobia results from the notion that lesbianism is a threat to heterosexuality and male superiority (Bunch, 2001). Some causes of homophobia, however, are not considered in this theory. For example, lesbian feminists did not consider that lack of contact with homosexuals might fuel homophobia. This is evident in that they advocated increased separation and isolation from men and non-lesbians (Stein, 1997). In addition to lack of contact, religious beliefs are not considered to be a cause of homophobia in this theory.

\section{Solutions and Implications}

Lesbian feminist theory offers a clear solution to homophobia: creating a group of like-minded women to influence society (Garber, 2001). The solution 
begins with creating such groups to form the lesbian feminist movement and eventually the lesbian nation. This nation would be one in which heterosexism was not superior and in which lesbians had equal opportunities and political power. In addition, lesbian feminism insists on political action and ending male supremacy; being a lesbian without action is not enough (Bunch, 2001). These individuals can challenge heterosexism by "denying women's 'innate' need for men" (Bunch, 2001, p. 129). Finally, this theory can serve as a basis for increasing social and community interventions for lesbians. In particular, lesbian feminists encourage programs where women are empowering and assisting other women.

\section{COMPARING THE TWO THEORIES}

Rawls' theory of social justice is a broad theory that can be easily applied to almost any social problem. The liberty and difference principles provide a way to tackle social injustices. Furthermore, by using the thought experiment of the original position, one can test considered judgments about society in order to see if these judgments are truly just. However, Rawls' theory is almost too broad in its nature. It does not adequately explain causes of social problems, such as homophobia. Furthermore, this theory is designed for a wellordered society in which all members will follow the principles of justice. In reality, there are people in society who break laws and commit unjust actions. This theory does not address how to handle these situations; thus, other theories are needed in order to fully understand homophobia.

Lesbian feminist theory, on the other hand, is very narrow in its scope. It is focused on the specific experience of lesbians in a heterosexist society. This theory does address the causes and solutions of a specific social problem, homophobia. Though lesbian feminism provides a unique and important perspective on homophobia, it does not encompass a wide variety of social problems. Therefore, this theory is a good counterpart to social justice theory in understanding homophobia.

\section{IMPLICATIONS FOR SOCIAL WORK PRACTICE}

The NASW (1999) Code of Ethics states that "social workers should obtain education about and seek to understand the nature of social diversity and oppression with respect to ... sexual orientation" (p. 9). This mandate is especially important in today's society; social workers often encounter homophobia and heterosexism in practice. Gays and lesbians may experience homophobia and heterosexism in the form of jokes, ridicule, and violent physical attacks (Garnets, Herek, \& Levy, 2003). In addition, these individuals are not afforded the rights given to heterosexuals, including the ability to adopt children, marry partners, or visit partners in the hospital.

Using the theoretical perspectives presented in this article, social work practitioners can assist their clients in a variety of ways. Rawls' theory of justice is helpful when organizing or planning educational seminars around homophobia and heterosexism. Social workers can present Rawls' concept of the original position in order to have attendees analyze these social issues. In addition to educational 
programs, Rawls' theory of justice provides a framework by which to advocatefor equal rights for gay, lesbian, bisexual, transgendered, and queer clients.

Social workers can also use the tenets of lesbian feminist theory to create support groups and networks of underrepresented individuals. According to this theory, it is important for women to empower each other and experience solidarity. By starting these support groups, social workers can ensure that women and other non-heterosexual community members encourage and empower each other.

In conclusion, no one theory is all-inclusive when practicing social work and doing research. Both lesbian feminism and Rawls' theory of justice provide distinctive and significant elements to the understanding of homophobia. As this article has demonstrated, it is only through using multiple perspectives and theories that inclusive comprehension can be achieved. In using a broad theory, such as social justice and a specific one like lesbian feminism, the framework for understanding homophobia highlights both macro and micro aspects of this issue.

\section{References.}

Buchanan, M., Dzelme, K., Harris, D., \& Hecker, L. (2001). Challenges of being simultaneously gay or lesbian and spiritual and/or religious: A narrative perspective. The American Journal of Family Therapy, 29(5), 435-449.

Bunch, C. (2001). Lesbians in revolt. In C. Bull (Ed.), Come out fighting: A century of essential writing on gay and lesbian liberation (pp. 126-131). New York: Nation Books.

Chalmers, A.F. (1999). What is this thing called science? Indianapolis, IN: Hackett Publishing Company, Inc.

Enns, C.Z. (1997). Feminist theories and feminist psychotherapies: Origins, themes, and variations. Binghamton, NY: Haworth Press.

Enns, C.Z., \& Sinacore, A.L. (Eds.). (2005). Teaching and social justice: Integrating multicultural and feminist theories in the classroom. Washington, D.C.: American Psychological Association.

Garber, L. (2001). Identity poetics: Race, classand thelesbian-feminist roots of Queer theory. NY: Columbia University Press.

Garnets, L.D., Herek, G.M., \& Levy, B. (2003). Violence and victimization of lesbians and gay men: Mental health consequences. In L.D. Garnets \& D.C. Kimmel (Eds.), Psychological perspectives on lesbian, gay, and bisexual experiences ( $2^{\text {nd }}$ ed., pp. 188-206). New York: Columbia University Press.

Hawkesworth, M. (2006). Feminist inquiry: From political conviction to methodological innovation. Piscataway, NJ: Rutgers University Press.

Jackson, S., \& Jones, J. (1998). Contemporary feminist theories. Edinburgh: Edinburgh University Press.

Jones, H. (1980). A Rawlsian discussion of discrimination. In H. Gene Blocker, \& E.H. Smith (Eds.), John Rawls' theory of social justice: An introduction (pp. 270-288). Athens, $\mathrm{OH}$ : Ohio University Press.

Kaufman, A. (2006). Rawls's practical conception of justice: Opinion, tradition and objectivity in political liberalism. Journal of Moral Philosophy, 3(1), 23-43.

Krieglstein, M. (2003). Heterosexism and social work: An ethical issue. In M. Sullivan (Ed.), Sexual minorities: Discrimination, challenges, and development in America (pp. 75-91). Binghamton, NY: The Haworth Social Work Practice Press.

Lehmann, P., \& Coady, N. (Eds.). (2001). Theoretical perspectives for direct social work practice: A generalist-eclectic approach. New York: Springer Publishing Company. 
Lorde, A. (2001). I am your sister: Black women organizing across sexualities. In C. Bull (Ed.), Come out fighting: A century of essential writing on gay and lesbian liberation (pp. 234-239). New York: Nation Books.

Magee, B. (1985). Philosophy and thereal world: An introduction to Karl Popper. La Salle, IL: Open Court Publishing Company.

Martin, D. (2002, November 26). John Rawls, theorist on justice, is dead at 82. TheNew York Times, p. C19.

Nathanson, S. (1998). Rawls's defense of the liberal democratic welfare state. In Economic Justice(pp. 8199). Upper Saddle River, NJ: Prentice Hall.

National Association of Social Workers. (1999). Code of Ethics. Washington, D.C.: NASW.

Noble, T. (2000). Introduction: Dimensions of the debate. In Social theory and social change (pp. 1-16). New York: St. Martin's Press.

Rawls, J. (1999). A theory of justice (Revised ed.). Cambridge, MA: The Belknap Press.

Rawls, J. (2001). On justice as fairness. In M. Clayton, \& A. Williams (Eds.), Social justice (pp. 49-84). Maldon, MA: Blackwell Publishing.

Saulnier, C.F. (1996). Lesbian feminist theory. In Feminist theories and social work: Approaches and applications (pp. 73-96). Binghamton, NY: The Haworth Press, Inc.

Simoni, J.M., \& Walters, K.L. (2001). Heterosexual identity and heterosexism: Recognizing privilege to reduce prejudice. Journal of Homosexuality, 41(1), 157-172.

Stein, A. (1997). Sisters and queers: The decentering of lesbian feminism. In R.N. Lancaster \& M. Di Leonardo (Eds.), The gender sexuality reader (pp. 378-391). New York: Routledge.

Sullivan, M. (Ed.). (2003). Homophobia, history, and homosexuality: Trends for sexual minorities. In M. Sullivan (Ed.), Sexual minorities: Discrimination, challenges, and development in America (pp. 1-13). Binghamton, NY: The Haworth Social Work Practice Press.

\section{Author's Note:}

Address correspondence to: Denise L. Levy, assistant professor, Department of Social Work, Chapell Wilson Hall, Appalachian State University, Boone, NC 28608, USA. e-mail: dllevy@gmail.com. 